\title{
Heilsugæsla í vanda
}

\section{Gunnlaugur Sigurjónsson}

heimilislæknir, Heilsugæslunni Árbæ stjórnarformaður Læknavaktarinnar

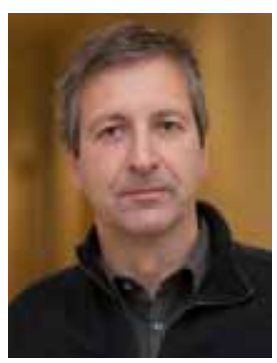

gunnlaugur.sigurjonsson@heilsugaeslan.is

Lög um heilsugæsluna voru sett árið 1973 og fljótlega var farið af stað með byggingu heilsugæslustöðva á landsbyggðinni. Rekstur heilsugæslunnar á landsbyggðinni gekk vel framan af og íslenskir læknar lögðu stund á pessa nýju sérgrein og komu heim fullir af metnaði og prótti. Hvað höfuðborgarsvæðið varðar varð minna úr efndum. Fyrsta heilsugæslustöðin opnaði í Árbæ árið 1977, en pað var ekki fyrr en árið 2006 að síðustu hverfin á höfuðborgarsvæðinu fengu sína heilsugæslustöð, Voga- og Heimahverfi. Рað var lengi óljóst hvernig ætti að standa að uppbyggingu heilsugæslunnar á höfuðborgarsvæðinu og margir höfuðborgarbúar eru enn ekki með heimilislækni.

Nýliðun í stétt heimilislækna var sáralítil á löngu tímabili í lok síðustu aldar og upphafi pessarar, hvort sem pað var vegna áhugaleysis stjórnvalda og borgaryfirvalda á heilsugæslunni eða aukinnar áherslu og áhuga lækna á hátæknilæknisfræði. Petta hefur orðið til pess að mönnun hefur gengið illa síðustu ár, bæði í dreifbýli og péttbýli. Sem betur fer hefur áhugi yngri lækna á heilsugæslunni glæðst á ný en samt er nýliðun heimilislækna innan við helmingur pess sem pyrfti, ef halda ætti í horfinu næstu ár.

Skortur á metnaði til að byggja heilsugæsluna á höfuðborgarsvæðinu almennilega upp hefur leitt til kulnunar í stétt heimilislækna og hafa margir horfið í önnur störf eða farið til útlanda á ný. Um 16\% lækna á Íslandi eru starfandi í heilsugæslunni. Í OECD-löndunum er meðaltalið tæplega 30\%. Kanada er dæmi um land par sem áhersla er lögð á heilsugæsluna og par eru um 47\% lækna starfandi í heilsugæslunni. Meðan hlutfall heimilislækna á Íslandi er petta lágt er borin von að heilsugæslan geti sinnt hlutverki sínu. Heimilislæknar upplifa pað аð geta engan veginn mætt pörfum og væntingum skjólstæðinga sinna. Læknar hafa talað fyrir daufum eyrum stjórnvalda um mikilvægi pess að efla heimilislækningar og tryggja að allir landsmenn hafi ákveðinn heimilislækni og geti náð í hann pegar pörf krefur. Árið 2007 var sett reglugerð 787/2007 sem gerði pað að verkum að hægt var að skrá sig á heilsugæslustöðvar án pess að velja ákveðinn lækni. Petta byggði upp væntingar fólks um að hægt yrði að fá fullnægjandi pjónustu heimilislækna en fyrir pví reyndist engin innistæða vegna skorts á læknum. Heimilislækningum, sem byggja á langtímasambandi læknis og sjúklings, var pannig gert mun erfiðara fyrir. Læknar sjá sífellt nýja sjúklinga sem peir pekkja ekki. Starfsemi heilsugæslustöðva hefur færst nær pví sem er á bráđamóttökum par sem leystur er aðkallandi bráður vandi en ekki boðið upp á samfellu og eftirfylgd fyrir fólk með langvinna sjúkdóma. Petta hefur aukið á kulnun í starfi hjá heimilislæknum og dregið úr peim möguleikum sem eru til forvarna í heilsugæslunni. Skilningur stjórnvalda á mikilvægi listunar sjúklinga hefur verið lítill og ekki hefur verið hægt að fá miðlæga skráningu fólks á heimilislækna pó nú hilli undir breytingar í pá átt í tengslum við nýtt fjármögnunarlíkan heilsugæslunnar.

Ungbarnavernd og mæðravernd eru dæmi um starfsemi sem er almennt í góðu horfi innan heilsugæslunnar og er rekin í teymisvinnu. Í dag er lögð áhersla á aukna teymisvinnu og aðkomu fleiri starfsstétta að heilsugæslunni. Ráđist hefur verið í skipulagsbreytingar á premur heilsugæslustöðvum í Reykjavík til að auðvelda stjórnun á slíkri vinnu. Aukin teymisvinna mun hins vegar ekki leysa pann skort sem er á heimilislæknum eða draga úr mikilvægi pess að allir séu með skráðan ákveðinn heimilislækni. Margir heimilislæknar hafa hrökklast úr starfi og geta ekki hugsað sér að starfa á ný innan heilsugæslunnar nema með meiri áhrifum á starfsumhverfi sitt. Krafa um fjölbreyttari rekstrarform og aukinn sjálfstæðan rekstur lækna hefur af peim sökum verið sett fram af vaxandi punga síðustu ár. Fordæmi eru fyrir sjálfstæðum rekstri lækna í heilsugæslunni. Pannig eru tvær heilsugæslustöðvar reknar af læknum, Lágmúli og Salastöð, og 12 heimilislæknar starfa utan heilsugæslustöðva. Einnig hafa heimilislæknar skipulagt og séð um vaktpjónustu á höfuðborgarsvæðinu í gegnum Læknavaktina Smáratorgi í áratugi. Mörg lönd sem við viljum gjarnan bera okkur saman við í heilbrigðismálum hafa séð kosti pess að heimilislækningar séu í formi sjálfstæðs reksturs læknanna. Pannig er pað til dæmis í Noregi og Danmörku. Aukinn sjálfstæður rekstur lækna mun hins vegar ekki leysa allan vanda heimilislækninga á Íslandi. Til pess parf aukið fjármagn inn í heilsugæsluna og að laða lækna markvisst аð henni. Sérhver Íslendingur parf einnig að hafa sinn eigin heimilislækni. Pá fyrst mun heilsugæslan geta gegnt hlutverki sínu sem fyrsti viðkomustaðurinn pegar leita parf til heilbrigðiskerfisins.

Icelandic primary health care in crisis

Gunnlaugur Sigurjónsson General Practioner Chairman of the Board of Læknavaktin 